\title{
Masalah Keagenan dalam Kontrak Bagi Hasil Perbankan Syariah di Indonesia
}

\section{Agency Problem in Profit Sharing Contract of Sharia Banks in Indonesia}

\author{
Kery Utami ${ }^{1}$, Budi Purwanto ${ }^{1 *}$, Tubagus Nur Ahmad Maulana ${ }^{2}$ \\ 1) Departemen Manajemen, Fakultas Ekonomi dan Manajemen, IPB Kampus Dramaga Bogor 16680 \\ ${ }^{2)}$ Sekolah Bisnis, Institut Pertanian Bogor, Kampus IPB Gunung Gede Bogor 16151
}

\begin{abstract}
The Principle of profit-sharing operation in Sharia bank is often utilized for financing. However, in its practice, the distribution of Sharia Bank funds be done at the equivalent cost. This might occur due to the agency predicament in which Sharia Commercial Bank become a liaison between the depositor and the debtor who bring money. By conducting panel analysis of regression data at 11 sharia commercial banks in Indonesia during period 2012.Q12016.Q4, it was found that financial problems happen chiefly because of adverse Sharia Banks and moral hazard which intentionally increase financing.
\end{abstract}

Keywords: agency problem, asymmetric information, non-performing financing, profit loss sharing, sharia banking.

\begin{abstract}
ABSTRAK
Prinsip bagi hasil menjadi dasar operasional Bank Umum Syariah dalam memenuhi kebutuhan pembiayaan. Namun, dalam praktiknya penyaluran pembiayaan Bank Umum Syariah didominasi oleh pembiayaan berbasis jual-beli yang bukan merupakan pembiayaan bagi hasil. Hal ini diduga karena adanya masalah keagenan dalam peran Bank Umum Syariah sebagai mitra baik dengan penabung maupun dengan peminjam dana, yang mengakibatkan tingginya risiko pembiayaan bagi hasil. Dilakukan analisis faktor-faktor yang mempengaruhi pembiayaan bermasalah sebagai indikasi terjadinya masalah keagenan dengan metode analisis regresi data panel pada 11 Bank Umum Syariah di Indonesia periode 2012.Q1-2016.Q4. Terdapat masalah keagenan oleh nasabah peminjam dana atas ketidakhati-hatian Bank Umum Syariah dalam menyalurkan pembiayaan bagi hasil.
\end{abstract}

Kata kunci: informasi asimetris, masalah keagenan, sistem bagi hasil, bank syariah.

*Corresponding author

Alamat e-mail: budipurwanto@apps.ipb.ac.id 


\section{PENDAHULUAN}

Industri Perbankan Indonesia mengadopsi sistem perbankan ganda yakni Bank Umum Konvensional dan Bank Umum Syariah yang secara implisit diatur dalam UU No. 7 Tahun 1992 tentang Perbankan dan dijabarkan secara rinci dalam Peraturan Pemerintah No. 72 Tahun 1992 tentang Bank Berdasarkan Prinsip Bagi Hasil atau disebut Bank Syariah. Perbedaan utama antar keduanya ialah Bank Konvensional menerapkan sistem perbankan berbasis bunga, sedangkan Bank Syariah menerapkan sistem perbankan bebas bunga (Hassan dan Lewis 2007). Sebagai alternatif sistem bunga pada Perbankan Konvensional, Perbankan Syariah menawarkan sistem bagi hasil atau disebut Profit Loss Sharing (PLS) (Yahya dan Agunggunanto 2011). Prinsip bagi hasil merupakan sebuah perjanjian kontrak diantara dua belah pihak yakni mudharib (pengelola dana) dan sahibul mal (pemilik dana) dimana masing-masing pihak menghimpun sumber daya, menginvestasikannya dalam suatu proyek usaha dan kemudian saling berbagi keuntungan dan kerugian (Hassan dan Lewis 2007).

Bagi hasil sebagai metode Bank Syariah dalam memenuhi kebutuhan kegiatan pendanaan yakni sebagai pemenuhan kebutuhan permodalan (equity financing) terdiri dari pembiayaan mudharabah dan musyarakah. Selain itu, terdapat juga pembiayaan dengan akad jual beli (al bai') atau disebut debt financing seperti murabahah, salam, istishna serta prinsip sewa-beli ijarah dan qardh (Rivai dan Arifin 2010).Pembiayaan bagi hasil menjadi esensi utama pembiayaan Syariah dan merupakan karakteristik dasar Bank Umum Syariah (Prasetyo dan Burhan 2013). Namun, dalam praktiknya penyaluran pembiayaan Bank Umum Syariah didominasi oleh pembiayaan berbasis jual-beli yang bukan merupakan pembiayaan bagi hasil (Gambar 1).

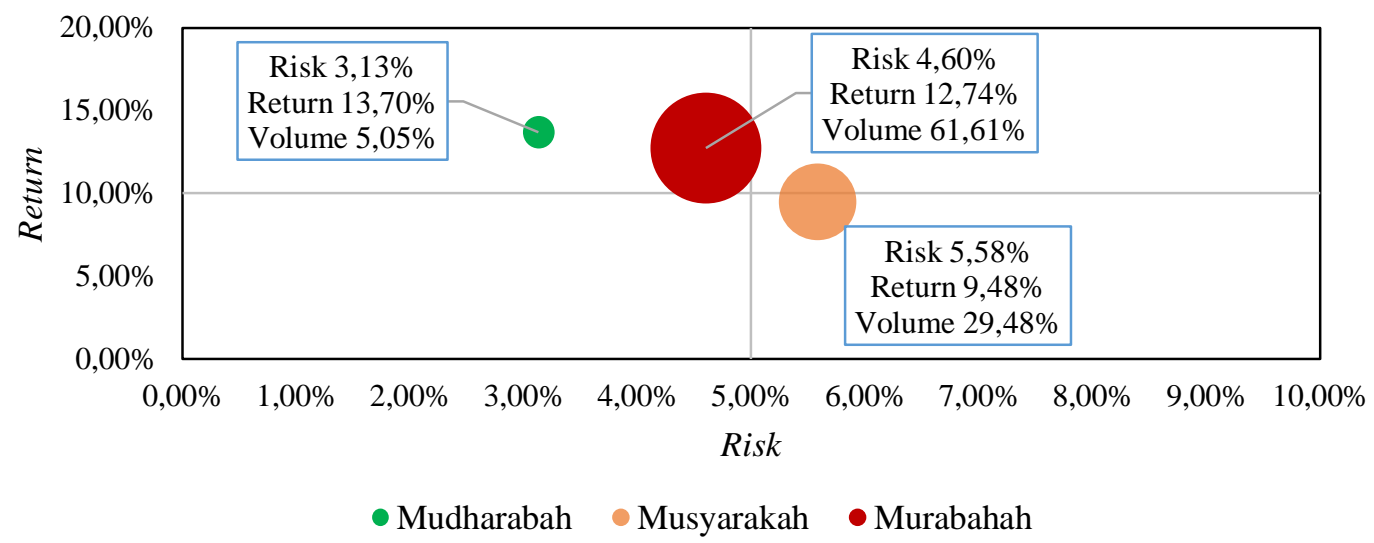

Gambar 1. Rata-rata volume penyaluran pembiayaan, risk dan return pembiayaan Bank Umum Syariah Sumber : Statistik Perbankan Syariah (2016)

Pada Gambar 1 terdapat perbandingan tiga jenis pembiayaan yang paling banyak disalurkan Bank Umum Syariah yakni mudharabah, musyarakah dan murabahah. Persentase penyaluran pembiayaan mudharabah dan musyarakah yang merupakan jenis pembiayaan bagi hasil jauh lebih rendah daripada penyaluran pembiayaan murabahah, dimana murabahah bukan merupakan akad bagi hasil melainkan pembiayaan dengan akad jual-beli. Ismal (2008) dalam kajiannya menyatakan bahwa besarnya portofolio murabahah disebabkan pembiayaan ini memiliki pendapatan yang pasti, berbeda dengan pembiayaan bagi hasil dimana pendapatan bank didasarkan pada keuntungan usaha riil nasabah sehingga tidak terdapat kepastian pendapatan.

Gambar 1 menunjukkan pembiayaan murabahah memiliki risiko dan pendapatan yang cenderung konstan, sementara pada pembiayan bagi hasil terdapat ketidakseimbangan antara risiko dan pendapatan. Pembiayaan mudharabah memiliki pendapatan tertinggi dengan risiko

Jurnal Manajemen dan Organisasi (JMO),

Vol. 9 No. 3 , Desember 2018, terendah (high return-low risk) dan pembiayaan musyarakah memiliki pendapatan terendah dengan risiko tertinggi (low return-high risk). Sejalan dengan El-Tiby (2011) yang menyatakan bahwa Bank Syariah yang menjalankan fungsi intermediasi berdasarkan sistem bagi hasil dapat 
menimbulkan risiko yang dapat menurunkan profitabilitasnya, yakni semakin besar risiko pembiayaan bagi hasil, pendapatan yang dihasilkan semakin rendah.

Menurut Aggarwal dan Yousef (2000); Dar dan Presley (2011) masalah keagenan melekat pada sistem Perbankan Syariah, hal ini menyebabkan pasokan pinjaman berbasis equity financing/profit loss sharing tidak meningkat. Masalah yang mungkin timbul adalah masalah informasi asimetris, terjadi ketidakseimbangan informasi dimana salah satu pihak memiliki lebih banyak informasi tentang diri mereka sendiri (termasuk niat dan kemampuan mereka) daripada orang lain. Ketidakseimbangan informasi memicu terjadinya konflik kepentingan dalam hubungan prinsipal agen atau dikenal masalah keagenan (Kurniawati 2008).

Dalam peran Bank Syariah sebagai mitra antara nasabah penabung (deposan) dan nasabah peminjam dana (debitur), terdapat hubungan kontrak antara pemilik dana/sahibul mal dan pelaku usaha/mudharib yang dikenal sebagai hubungan prinsipal-agen atau hubungan keagenan (Harahap 2016). Hubungan keagenan muncul ketika seseorang (prinsipal) mempekerjakan orang lain (agen), memberikan suatu jasa dan mempercayakan wewenang pengambilan keputusan kepada agen tersebut (Jensen dan Meckling 1976). Berdasarkan definisi tersebut, agen adalah seseorang yang membuat keputusan ekonomi untuk orang lain (Manzilati 2011).

Menurut Aggarwal dan Yousef (2000), Bank Syariah memiliki peran ganda yaitu sebagai prinsipal dan agen. Salah satunya ketika Bank bertindak sebagai agen, bank menerima dan mengelola dana dari deposan untuk menghasilkan keuntungan, dengan mempergunakan dana tersebut pada sisi portofolio investasi salah satunya ialah pembiayaan bagi hasil. Dalam prinsip bagi hasil, tingkat pengembalian pemegang rekening investasi bergantung pada seberapa baik kinerja bank secara finansial yang sebagin besar ditunjukkan oleh tindakan dan perilaku manajemen sebagai agen (Farag 2016).

Teori agensi mendominasi tata kelola perusahaan dimana tata kelola yang baik sering ditafsirkan pada orientasi maksimalisasi nilai. Dengan berfokus pada maksimalisasi nilai, berarti berorientasi pada masalah agensi yang sering digambarkan oleh keuntungan dan kepentingan pribadi (Farag 2017). Secara khusus, Bank Syariah diwajibkan untuk beroperasi dengan cara yang sesuai Syariah selain memaksimalkan kekayaan pemegang saham mereka, di sinilah letak risiko oportunisme dari para pengelola Bank Syariah untuk mengambil keuntungan pribadi dengan mengorbankan kepentingan deposan (Abdel dan Archer 2006). Hal ini mungkin terjadi mengingat keputusan investasi yang diambil oleh bank tidak dapat dipantau oleh deposan (Hamza 2015).

Selain itu, Bank Syariah memiliki insentif untuk mengambil risiko berlebih, dengan mengalokasikan simpanan dalam aset dengan risiko tinggi (excessive risk taking) (Hamza 2015). Ketidakhati-hatian bank dalam menyalurkan dana pihak ketiga dapat dikategorikan sebagai tindakan moral hazard (Wiliasih 2005). Moral hazard dalam dunia perbankan dapat dibedakan atas dua tingkatan, yakni moral hazard pada tingkat bank dan yang kedua adalah moral hazard di tingkat nasabah. Moral hazard pada tingkat bank dibedakan atas beberapa, diantaranya: a) moral hazard langsung akibat adanya risky lending behavior dalam penyaluran dana pihak ketiga yang menyebabkan timbulnya moral hazard dan adverse selection di tingkat nasabah; b) moral hazard langsung akibat adanya penjaminan dari pemerintah atau keberadaan lembaga penjamin simpanan timbul ketidakhati-hatian bank dalam menyalurkan kredit; c) ketidaksesuaian penyaluran dana oleh bank sebagai lembaga intermediasi; d) moral hazard ketika bank memberikan cost of fund rendah dan menerapkan tingkat yang tinggi, juga termasuk kategori moral hazard (Wiliasih 2005).

Sedangkan moral hazard pada nasabah debitur dapat terjadi sebagai berikut: a) jika peminjam terlibat dalam aktivitas yang tidak diinginkan dari sudut pandang pemberi pinjaman, karena mereka kemungkinan kecil akan melunasi pinjamannya; b) kondisi dimana mudharib bersifat risk averse (cenderung menghindari risiko), ia akan lebih memilih level upaya ditingkat yang hanya sekedar memenuhi tingkat utilitas minimal saja; c) ketidaksesuaian pelaporan jumlah profit, dalam hal ini mudharib memanipulasi jumlah profit yang dihasilkannya (Ardiansyah 2014). Hal ini dapat disebut juga sebagai adverse selection yakni ketidakmampuan para prinsipal untuk meneliti sifat-sifat agen, sulit bagi prinsipal untuk memastikan apa yang agen lakukan, prinsipal tidak dapat memastikan bahwa agen berperilaku dengan tepat (Eisenhardt 1989). Hal ini 
dikarenakan agen lebih mengetahui kondisi bisnis, sementara prinsipal tidak dapat mengamati langsung setiap aktifitas dan keputusan agen. Kontrak berbasis profit loss sharing (PLS) memiliki tingkat adverse selection dan moral hazard yang tinggi (Sadr dan Iqbal 2002). Adverse selection dan moral hazard melekat pada kontrak bagi hasil sebagai bentuk permasalahan atas ketidakseimbangan informasi (asymmetric information) dalam hubungan antara pemilik modal (sahibul mal/prinsipal) dan pelaku usaha (mudharib/agen) (Harahap 2016).

Dalam hal ini deposan menghadapi risiko kegagalan pengelolaan dana oleh bank yang akan meningkatkan pembiayaan bermasalah. Selain itu kedudukan pemberi pinjaman/bank juga berada dalam posisi penerima risiko atas usaha yang dilakukan pihak peminjam dana atau agen (Ibrahim dan Ragimun 2010) dan akan berdampak pada kualitas pembiayaan, karena setiap pembiayaan yang disalurkan memiliki risiko pembiayaan yang tinggi. Seperti yang dinyatakan oleh Wiliasih (2005) masalah keagenan seperti moral hazard dan adverse selection mengakibatkan tingginya NPF (non- performing financing). Semakin tinggi rasio ini, menunjukkan kualitas pembiayaan Bank Syariah semakin buruk akibat adanya masalah keagenan. Menurut Idroes (2011), pembiayaan bermasalah akan berakibat pada kerugian tidak diterimanya kembali dana yang telah disalurkan, maupun pendapatan yang tidak dapat diterima. Karena berbagai sebab, debitur mungkin saja menjadi tidak memenuhi kewajibannya kepada bank (terjadi moral hazard oleh debitur). Artinya, bank kehilangan kesempatan mendapat penerimaan yang sebelumnya sudah diperkirakan, yang berakibat pada penurunan pendapatan secara total.

Berdasarkan uraian diatas, perlu dilakukan penelitian masalah keagenan dalam kontrak bagi hasil perbankan Syariah di Indonesia dengan menganalisis indikasi terjadinya masalah keagenan. Masalah keagenan ini diketahui memicu pembiayaan bermasalah dalam kontrak bagi hasil sehingga berdampak pada rendahnya pendapatan serta penerapan kontrak bagi hasil perbankan Syariah. Hal ini didasarkan pada karakteristik sistem perbankan Syariah yang beroperasi berdasarkan prinsip bagi hasil diarahkan untuk memberikan kemaslahatan terbesar bagi masyarakat dan berkontribusi secara optimal bagi perekonomian nasional (BI).

\section{METODE PENELITIAN}

Pembiayaan bermasalah diduga merupakan cerminan adanya masalah keagenan. Faktor pemicu pembiayaan bermasalah dianalisis melalui beberapa rasio potensinya terhadap pembiayaan bermasalah diantaranya:

\section{Intensitas Fungsi Agensi (FA)}

Bank Indonesia menetapkan intensitas fungsi agensi Bank Syariah sebagai salah satu komponen faktor permodalan untuk mengukur fungsi agensi Bank Syariah atau agency ratio (AR), dengan membandingkan dana pihak ketiga berbasis profit sharing (DPKps) dengan total dana pihak ketiga. Semakin besar AR maka biaya sistemik saat likuidasi semakin kecil, Apabila biaya sistemik likuidasi menurun maka kebutuhan financial safety net (FSN) turun. Dapat diartikan bahwa dengan tingginya DPKps, bank telah menurunkan ketergantungan terhadap FSN karena besarnya DPKps menunjukkan besarnya penyertaan modal yang tidak perlu ditanggung oleh FSN.

Sebaliknya, rendahnya AR yakni rendahnya DPKps menunjukkan bahwa DPK masih didominasi oleh DPKnon-ps, dimana DPK non-ps bukan suatu penyertaan modal melainkan pinjaman yang harus digantikan saat terjadi likuidasi, hal ini tentu akan meningkatkan biaya saat likuidasi. untuk mengatasi hal ini, bank memerlukan FSN yang lebih tinggi untuk menjamin DPK non-ps. Hal ini, dapat mendorong terjadinya moral hazard oleh Bank Syariah. Moral hazard terjadi atas ketidakhati-hatian bank dalam memanfaatkan dominasi DPK yang sudah atau tidak dijaminkan pada FSN. Ketidaksesuaian penggunaan sumber dana dengan pembiayaan yang disalurkan, bank dihadapkan pada risiko pembiayaan bermasalah.

Jurnal Manajemen dan Organisas (JMO),

Vol. 9 No. 3 , Desember 2018,

\section{Investment Appeal (IA)}

Besarnya bagi hasil dana investasi merupakan suatu komponen faktor rentabilitas yang membandingkan distribusi bagi hasil profit sharing dengan DPK profit sharing, dimana data 
distribusi bagi hasil profit sharing adalah besarnya bagi hasil bagi investor dana investasi (deposan profit sharing). Pengukuran ini dilakukan untuk mengetahui kemampuan bank dalam mengelola dana investasi untuk menghasilkan pendapatan bagi deposan profit sharing. Menurut Hamza (2015) pengembalian terhadap investment account holder (IAH) (deposan profit sharing) mencerminkan kemampuan bank dalam memberikan pengembalian yang kompetitif. Dalam hal ini, bank menghadapi displaced commercial risk. Displaced commercial risk disebabkan oleh adanya potensi nasabah memindahkan dananya yang didorong oleh tingkat bonus atau bagi hasil riil yang lebih rendah daritingkat suku bunga (Kodifikasi PBI). Dan memungkinkan bank untuk melakukan excessive risk taking guna menghasilkan pendapatan yang tinggi agar tetap memberikan pengembalian yang kompetitif pada deposan. Namun, hal ini dihadapi risiko yang cukup tinggi yaitu risiko pembiayaan bermasalah yang timbul dari perilaku excessive risk taking, sehingga bank mengalami penurunan pendapatan dan perlu membentuk pencadangan atas pembiayaan bermasalah. Seperti yang dinyatakan oleh El-Tiby (2011) bahwa profit loss sharing memiliki risiko yang dapat menurunkan profitabilitasnya, yaitu displaced commercial risk.

\section{Financing to Deposit Ratio (FDR)}

Fungsi intermediasi menjadi Fungsi utama bank, dimana fungsi intermediasi ini dapat ditunjukkan oleh Financing to Deposit Ratio (FDR). Rasio ini digunakan untuk mengukur dana pihak ketiga yang disalurkan dalam bentuk kredit/pembiayaan. Penyaluran pembiayaan merupakan kegiatan utama bank, dan merupakan sumber pendapatan utama bank. FDR menggambarkan kemampuan Bank Syariah membayar kembali penarikan yang dilakukan oleh nasabah dengan mengandalkan pembiayaan yang diberikan sebagai sumber likuiditasnya (Astrini et al. 2014).

Semakin tinggi penyaluran kredit menggunakan DPK, maka fungsi intermediasi bank berjalan baik (Siringoringo 2012). Akan tetapi, semakin besar penyaluran dana dalam bentuk pembiayaan dibandingkan dengan deposit atau simpanan masyarakat pada suatu bank, membawa konsekuensi semakin besarnya risiko likuiditas yang harus ditanggung oleh bank yang bersangkutan. Sebaliknya, rendahnya penyaluran kredit menggunakan DPK menunjukkan fungsi intermediasi tidak berjalan dengan lancar, karena DPK tidak disalurkan pada sektor riil (Siringoringo 2012). Islam dan Nishiyama (2016) menyatakan bahwa kelebihan likuiditas merupakan proxy masalah moral hazard antara manajemen bank dan deposan karena deposan tidak dapat memantau dan membuat manajemen terikat untuk pemanfaatan dana secara efektif. Dengan kata lain, deposan, sebagai pihak ketiga tidak dapat memantau biaya kelebihan likuiditas namun terkena dampak masalah moral hazard oleh bank dan berakibat pada timbulnya kredit macet pembiayaan.

\section{Restrukturisasi Pembiayaan (RP)}

Merupakan salah satu analisis komponen faktor penentuan kualitas aset untuk mengukur efektifitas kegiatan bank dalam melakukan restrukturisasi penyaluran dana, dengan mengukur perkembangan posisi yang direstrukturisasi terhadap total pembiayaan. Semakin besar pertumbuhan rasio ini mengindikasikan rendahnya kualitas pengambilan keputusan dalam penyaluran pembiayaan sehingga berdampak pada pembiayaan yang harus direstrukturisasi (Kodifikasi PBI). Masalah yang mungkin timbul ialah adverse selection dalam penyaluran pembiayaan, dimana nasabah potensial justru beresiko tinggi. Hal ini menunjukkan bahwa efektifitas kegiatan bank dalam melakukan restrukturisasi cenderung rendah sehingga meningkatkan pembiayaan bermasalah berkelanjutan. Dengan begitu, pertumbuhan rasio restrukturisasi bisa menjadi sebuah indikasi adanya peningkatan NPF. Secara keseluruhan, definisi operasional dan pengukuran variabel dapat dilihat pada Tabel 1. 
Tabel 1. Definisi Operasional dan Pengukuran Variabel

\begin{tabular}{|c|c|c|}
\hline Variabel & Pengukuran Variabel & Arah Pengaruh \\
\hline \multirow{2}{*}{$\begin{array}{l}\text { Non-Performing Financing- } \\
\text { profit sharing (NPFps) }\end{array}$} & Pembiayaan $_{\text {profit sharing }}(\mathrm{KL}, \mathrm{D}, \mathrm{M})$ & \\
\hline & Total Pembiayaan $_{\text {profit sharing }}$ & \\
\hline \multirow{2}{*}{$\begin{array}{l}\text { Intensitas Fungsi Agensi } \\
\text { (FA) }\end{array}$} & $\mathrm{DPK}_{\text {profit sharing }}$ & Negatif (-) \\
\hline & $\mathrm{DPK}_{\text {total }}$ & \\
\hline \multirow{2}{*}{ Investment Appeal (IA) } & Distribusi bagi hasil ${ }_{\text {profit sharing }}$ & Negatif (-) \\
\hline & $\mathrm{DPK}_{\text {profit sharing }}$ & \\
\hline \multirow{2}{*}{$\begin{array}{l}\text { Financing to Deposit Ratio- } \\
\text { profit sharing (FDRps) }\end{array}$} & Pembiayaan Bagi Hasil & \multirow[b]{2}{*}{ Negatif (-) } \\
\hline & $\mathrm{DPK}_{\text {profit sharing }}$ & \\
\hline $\begin{array}{l}\text { Pertumbuhan Restrukturisasi } \\
\text { Pembiayaan-profit sharing }\end{array}$ & Restrukturisasi $_{p s} t / \mathrm{P}$ & \multirow[t]{2}{*}{ Positif (+) } \\
\hline RPps) & $\overline{\text { Restrukturisasi }_{p s} t-1 / \text { Pembiayaan }_{p s} t-1}$ & \\
\hline
\end{tabular}

Sumber: Kodifikasi PBI

Metode empiris penelitian ini didasarkan pada analisis data panel, bersumber dari laporan keuangan triwulan Bank Umum Syariah yang dipublikasikan Bank Indonesia dan Otoritas Jasa Keuangan periode 2012-2016. Analisis ini melibatkan sumber data bersifat antar unit (cross section) terdiri dari 11 Bank Umum Syariah yang dipilih dengan metode purposive sampling dan data bersifat antar waktu (time series) periode 2012.Q1-2016.Q4 atau disebut data panel. Pemilihan model regresi ditentukan oleh jenis data yang digunakan, oleh karena itu metode regresi yang digunakan ialah regresi data panel. Estimasi regresi data panel dilakukan dengan bantuan software E-views 10. Persamaan model data panel yang digunakan sebagai berikut:

$\mathrm{NPFps}_{i t}=\beta_{0}+\beta_{1} \mathrm{FA}_{\mathrm{it}}+\beta_{2} \mathrm{IA}_{\mathrm{it}}+\beta_{3} \mathrm{FDRps}_{\mathrm{it}}+\beta_{4} \mathrm{RPps}_{\mathrm{it}}+\varepsilon$

Keterangan Variabel:

NPFps : Non-Perfoming Financing profit sharing

FA : Fungsi Agensi

IA : Investment Appeal

FDRps : Financing to Deposit Ratio profit sharing

RPps : Restrukturisasi Pembiayaan profit sharing

Bermula dari pemilihan model estimasi terbaik yakni antara common effect dengan fixed effect melalui uji f-restricted, selanjutnya fixed effect dengan random effect melalui Uji Hausman dan terakhir random effect dengan common effect melalui uji LM pada masing-masing persamaan. Selanjutnya dilakukan analisis uji signifikansi masing-masing persamaan melalui uji koefisien determinasi dilanjutkan dengan uji hipotesis simultan dan parsial.

\section{HASIL DAN PEMBAHASAN}

Menurut SPS (2016), jumlah Bank Umum Syariah di Indonesia sebanyak 13 bank. Yang menjadi sampel dalam penelitian ini hanya 11 Bank Umum Syariah. Hal ini disebabkan 2 bank lainnya tidak memenuhi kriteria purposive sampling. Daftar Bank Umum Syariah yang terpilih menjadi sampel ditampilkan pada Tabel 2 . 
Tabel 2. Daftar sampel Bank Umum Syariah

\begin{tabular}{rlll}
\hline \multicolumn{1}{c}{ No } & \multicolumn{1}{c}{ Kode Bank } & \multicolumn{1}{c}{ Nama Bank } & Tahun Beroperasi \\
\hline 1 & BCAS & PT. BCA Syariah & 5 April 2010 \\
2 & BJBS & PT. Bank Jabar Banten Syariah & 15 Januari 2010 \\
3 & BMI & PT. Bank Muamalat Indonesia & 1 Mei 1992 \\
4 & BMSI & PT. Bank Mega Syariah Indonesia & 25 Agustus 2004 \\
5 & BNIS & PT. Bank BNI Syariah & 19 Juni 2010 \\
6 & BRIS & PT. Bank BRI Syariah & 17 November 2008 \\
7 & BSM & PT. Bank Syariah Mandiri & 1 November 1999 \\
\hline 8 & BUKOPINS & PT. Bank Syariah Bukopin & 9 Desember 2008 \\
9 & MYBS & PT. Maybank Syariah Indonesia & 11 Oktober 2010 \\
10 & PANINS & PT. Bank Panin Syariah & 2 Desember 2009 \\
11 & VICTORIAS & PT. Bank Victoria Syariah & 1 April 2010
\end{tabular}

Sumber: SPS 2016

Berdasarkan uji pemilihan model dalam regresi data panel, dihasilkan fixed effect sebagai model terbaik, dengan output pada Tabel 3.

Tabel 3. Fixed Effect Model

\begin{tabular}{|c|c|c|}
\hline Variabel & Coefficient & Prob. \\
\hline$\overline{\mathrm{C}}$ & 0,253218 & 0,0000 \\
\hline $\mathrm{FA} \rightarrow$ NPFps & $-0,190281$ & 0,0036 \\
\hline $\mathrm{IA} \rightarrow \mathrm{NPFps}$ & $-0,244643$ & 0,0092 \\
\hline FDRps $\rightarrow$ NPFps & $-0,039611$ & 0,0681 \\
\hline $\mathrm{RPps} \rightarrow \mathrm{NPFps}$ & $-4,99 \mathrm{E}-05$ & 0,8901 \\
\hline
\end{tabular}

Adjusted R-Square : 0,732178

F-Statistik : 32,54416

Prob (F-Statistik) : 0,000000

Sumber: Output Eviews 10

Berdasarkan Tabel 3, dapat dibuat persamaan regresi sebagai berikut:

NPFps $=0,253218-0,190281$ FA $-0,244643$ IA $-0,039611$ FDRps $-4,99 \mathrm{E}-05$ RPps

Melalui uji F Simultan dimana nilai signifikansi yakni sebesar 0,000000 lebih kecil dari taraf nyata 0,05 dapat diartikan bahwa secara bersama-sama variabel FA, IA, FDRps dan RPps berpengaruh signifikan terhadap NPFps. Dengan kemampuan menjelaskan oleh variabel independen sebesar 73,2178 persen sementara 26,7822 persen sisanya dijelaskan oleh variabel lain yang tidak dicakup dalam penelitian ini. Selanjutnya berdasarkan uji t-Parsial diperoleh hasil bahwa FA dan IA berpengaruh signifikan menurunkan NPFps pada taraf nyata 5 persen. Setiap kenaikan 1persen FA akan menurunkan NPFps sebesar 0,190281 persen, sebaliknya setiap penurunan 1persen FA akan menaikkan NPFps sebesar 0.190281 persen. Sedangkan setiap kenaikan 1persen IA, akan menurunkan NPFps sebesar 0,244643persen begitu juga sebaliknya setiap penurunan 1persen IA, akan menaikkan NPFps sebesar 0,244643 persen. Hal ini menunjukkan bahwa hipotesis satu dan dua dimana Fungsi Agensi dan Investment Appeal signifikan berpengaruh negatif terhadap NPFps. Sejalan dengan Iqbal et al. (2007), bahwa fungsi agensi dan investment appeal merupakan rasio finansial dalam menilai masalah keagenan perbankan.

Bank Syariah adalah bank yang melaksanakan kegiatan usaha berdasarkan prinsip Syariah, dimana aturan perjanjian antara bank dan pihak lain untuk menghimpun dana dan menyalurkan dana dalam bentuk pembiayaan kegiatan usaha atau kegiatan lainnya dinyatakan sesuai dengan syariah. 


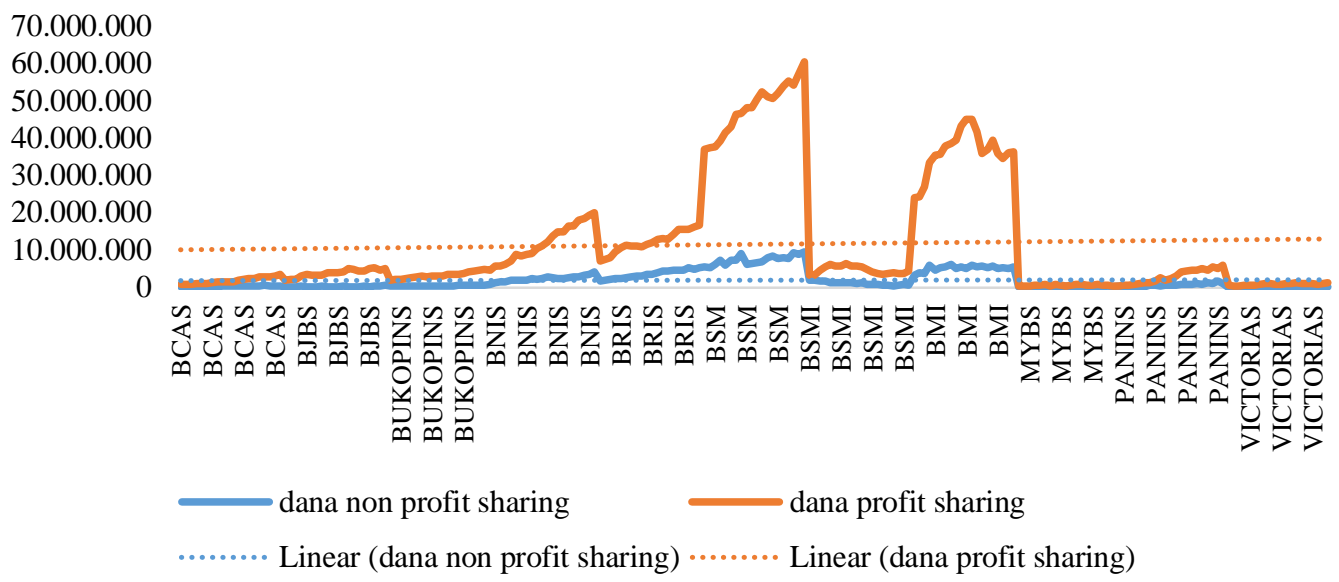

Gambar 2. Sumber Dana Bank Syariah

Sumber dana yang dihimpun oleh Bank Umum Syariah dikategorikan dana non-profit sharing dan dana profit sharing dengan tren dominasi sumber dana menunjukkan bahwa sebagian besar sumber dana Bank Syariah berasal dari dana profit sharing (Gambar 2) yang mana dana ini dihimpun, dikelola dan dikembalikan berdasarkan prinsip bagi hasil. Tingginya sumber dana profit sharing menunjukkan kemampuan fungsi agensi Bank Syariah. berdasarkan persamaan regresi data panel membuktikan bahwa setiap kenaikan Fungsi Agensi akan menurunkan NPFps atau dapat pula menaikkan NPFps apabila Fungsi Agensi menurun.

Berdasarkan rata-rata fungsi agensi masing-masing bank pada Gambar 3 menunjukkan bahwa Fungsi Agensi dan pembiayaan bermasalah masuk dalam kuadran Higher FA-Lower NPFps. Semakin tinggi Fungsi Agensi disalurkan ke pembiayaan PLS, NPFps semakin rendah karena dalam hal bank mengalokasikan dana untuk pembiayaan bagi hasil, maka bank bertanggung jawab atas likuiditas dana tersebut, karena pembiayaan bagi hasil terjadi berdasarkan distribusi keuntungan dan kerugian bersama (Usanti 2006). Oleh karena itu, Bank Syariah sebagai mudharib menjadi wali amanah yang harus berhati-hati dan bertanggung jawab atas segala sesuatu yang timbul akibat kesalahan atau kelalaiannya guna meminimalisir risiko.

\section{FA to NPFps}

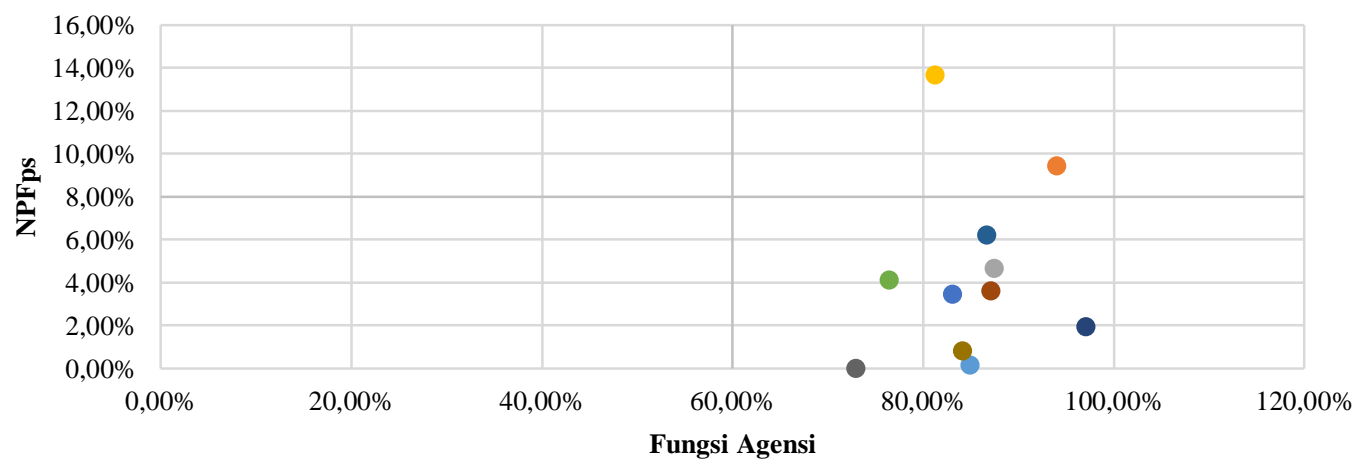

- BCAS • BJBS • BMI $\bullet$ BMSI • BNIS • BRIS • BSM • BUKOPINS • MYBS • PANINS • VICTORIAS

Gambar 3. Fungsi Agensi Bank Syariah dan Non-Performing Financing Profit Sharing

Hal ini menunjukkan suatu kebijakan Bank Syariah dimana semakin tinggi Fungsi Agensi, semakin bank menjaga kepercayaan deposan dengan menyalurkan pembiayaan murabahah (nonPLS). Mengingat akad pembiayaan bagi hasil sangat rentan terhadap masalah moral hazard. Gambar 4 menunjukkan bahwa alokasi pembiayaan non-PLS lebih besar daripada pembiayaan PLS. Sebagai alternatif pembiayaan bagi hasil, Bank Syariah banyak menyalurkan pembiayaan musyarakah (Gambar 1). Karena pada pembiayaan musyarakah masing-masing pihak berkontrak 
sama-sama memberikan kontribusi modal dan semua mitra turut berpartisipasi dalam manajemen, tidak hanya agen. Tidak seperti pembiayaan mudharabah, Bank Syariah sebagai satu-satunya pihak penyedia dana dengan manajemen ditetapkan atas salah satu mitra (agen), prinsipal hanya mendapat bagian laba sebagai imbalan atas modal mereka (kemitraan tidak aktif).

Meskipun bank cukup berhati-hati dalam mengalokasikan dana pihak ketiga, namun ada kewajiban yang belum maksimal dijalankan oleh BUS yakni rendahnya penyaluran pembiayaan bagi hasil guna memberikan pengembalian atas dana yang dipercayakan deposan berdasarkan prinsip bagi hasil. Pengaruhnya Fungsi Agensi terhadap NPFps ini menunjukkan bahwa bank risk averse terhadap pembiayaan bagi hasil, dan juga terjadinya moral hazard karena bank tidak menyalurkan dana tersebut pada sektor seharusnya. Hal ini sejalan dengan penelitian yang dilakukan oleh Kurniawati (2016) bahwa berdasarkan analisis risk dan return menunjukkan bahwa Bank Umum Syariah bersifat risk averse, sehingga BUS kurang preferable terhadap PLS.

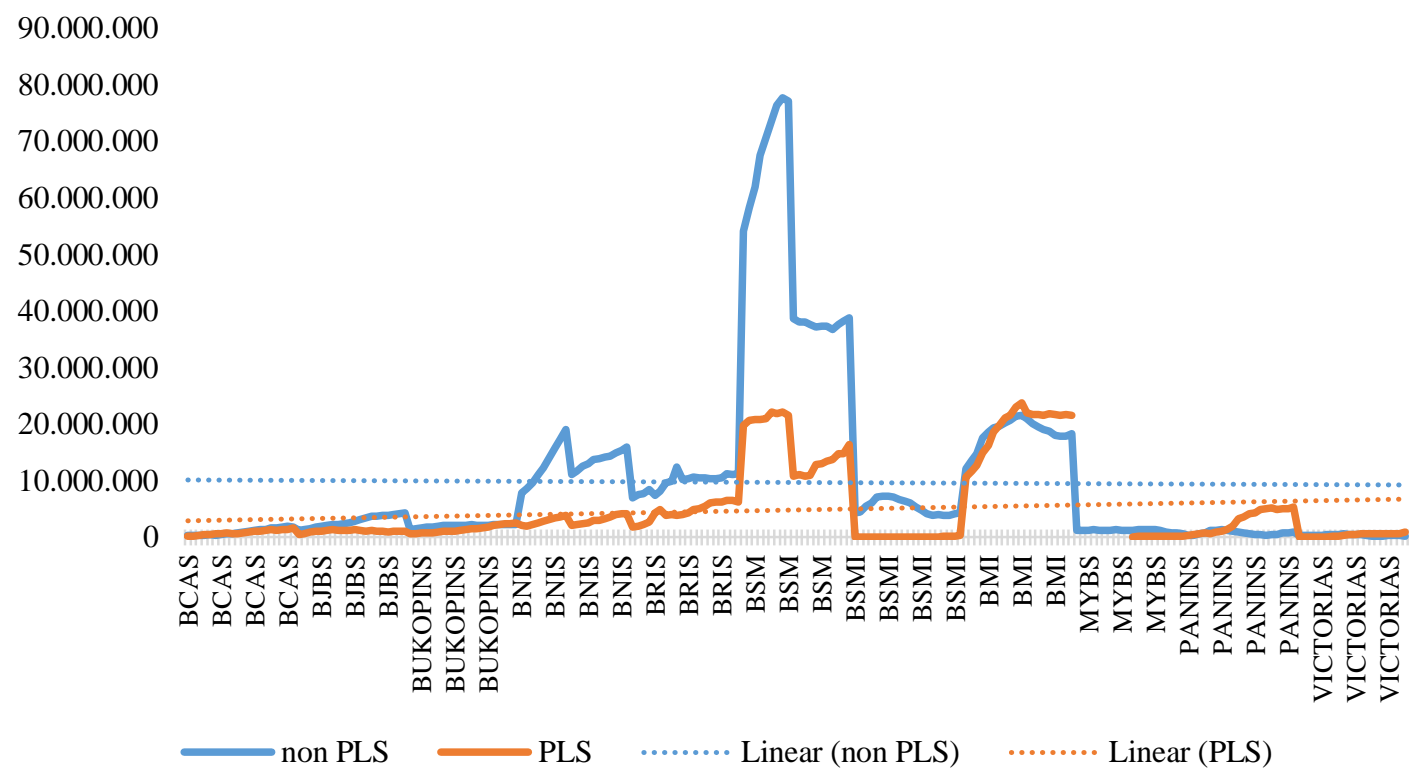

Gambar 4. Alokasi Pembiayaan Bank Umum Syariah

Selain Fungsi Agensi sebagai salah satu komponen faktor permodalan Bank Syariah, faktor lainnya yakni Investment Appeal (IA) juga berpengaruh negatif dan signifikan terhadap NPFps. Berdasarkan hasil analisis regresi, setiap kenaikan IA akan menurunkan NPFps dan juga sebaliknya setiap penurunan IA justru akan meningkatkan NPFps. Hal ini menunjukkan bahwa kemampuan bank dalam mengelola dana investasi dan memberikan return bagi deposan profit sharing berdampak pada NPFps. Semakin tinggi IA menunjukkan kemampuan bank tersebut semakin baik. Bank dapat memonitor pembiayaan bagi hasil dengan baik, sehingga menghasilkan pendapatan untuk memberikan pengembalian yang kompetitif kepada deposan. Sebaliknya rendahnya IA akan mendorong bank untuk memaksimalkan pendapatan dan rentan dengan keputusan berisiko seperti pada Gambar 1, bank lebih memilih menyalurkan pembiayaan musyarakah dimana NPF yang dihasilkan lebih besar daripada pembiayaan mudharabah.

Selain itu, dalam hal distribusi bagi hasil untuk pemilik dana profit sharing, terdapat kontribusi return pembiayaan yakni diantaranya return pembiayaan murabahah dan return pembiayaan bagi hasil. Jika dikaitkan antara return yang diperoleh dengan alokasi pembiayaan, maka besarnya pembiayaan yang dialokasikan oleh suatu bank terlihat sangat terkait kepada return yang diperoleh dari pembiayaan tersebut (Wiliasih 2005). Pada Gambar 5, dapat diketahui bahwa pendapatan atas pembiayaan murabahah berkontribusi besar terhadap pengembalian kepada deposan. Rendahnya penyaluran pembiayaan bagi hasil menyebabkan rendahnya pendapatan atas pembiayaan bagi hasil, sehingga kontribusi pengembalian untuk deposan cukup rendah. Pengaruhnya Investment Appeal terhadap NPFps ini menunjukkan bahwa dalam 
memberikan pengembalian kepada deposan, bank mengandalkan pembiayaan dengan tingkat return yang dapat diprediksi secara pasti seperti murabahah daripada pembiayaan bagi hasil.

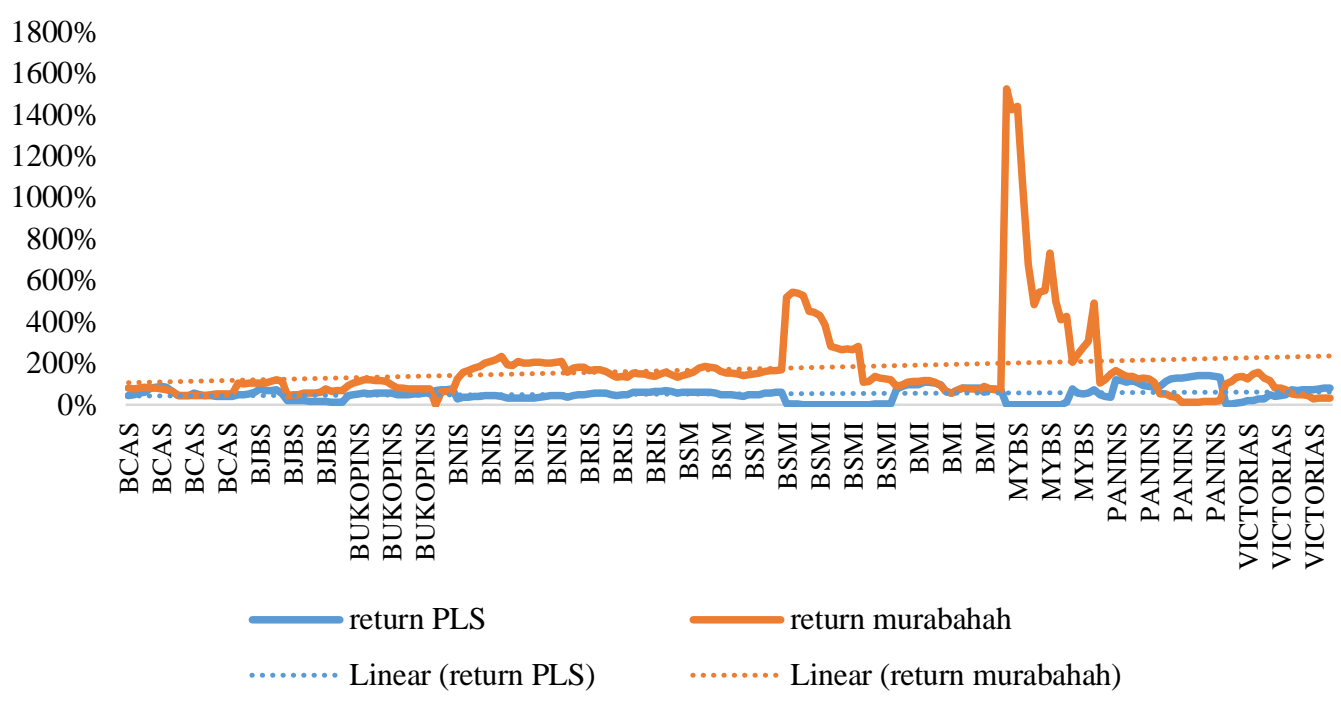

Gambar 5. Kontribusi Distribusi Bagi Hasil Deposan

Hal berbeda terjadi pada Financing to Deposit Ratio profit sharing (FDRps) dan Pertumbuhan Restrukturisasi Pembiayaan profit sharing (RPps). Kedua variabel tidak signifikan berpengaruh terhadap NPFps. Namun terdapat beberapa informasi yang diperoleh seperti pada Gambar 6.

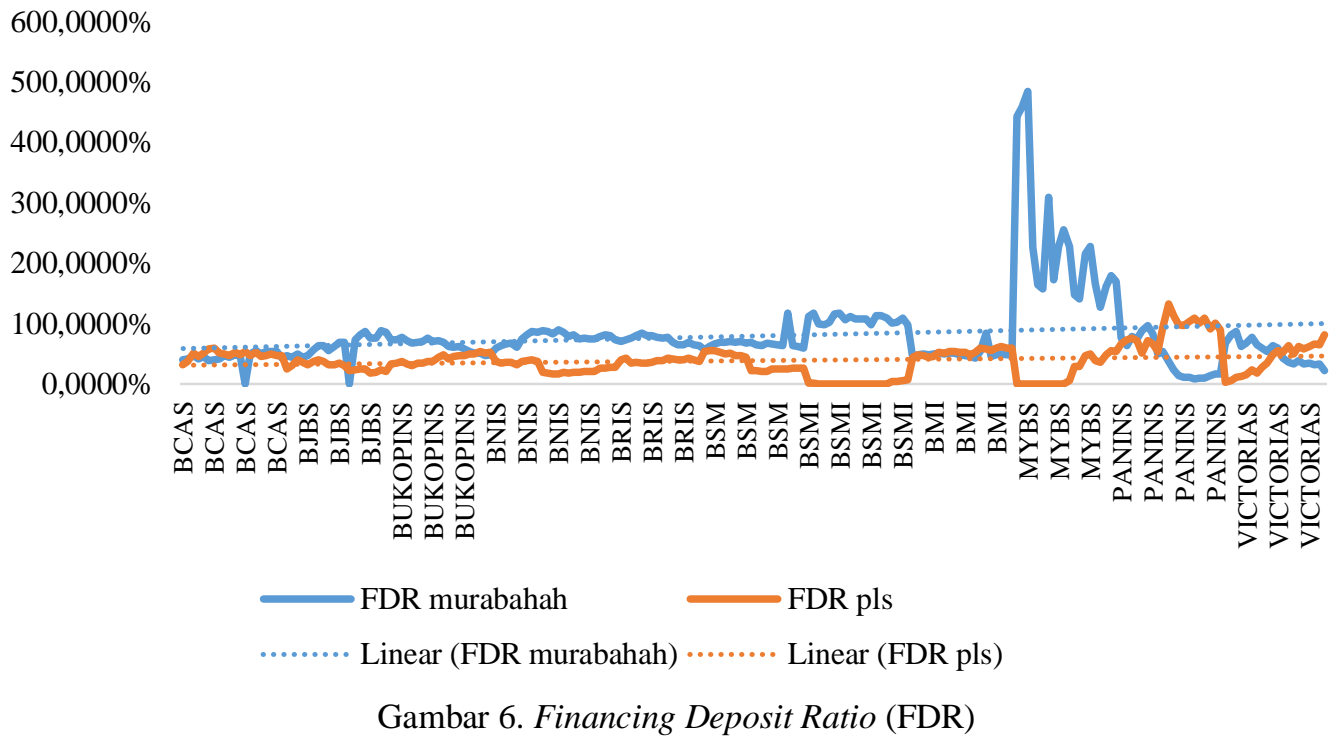

Rendahnya FDRps dengan rata-rata sebesar 52.7568 persen menandakan bank sebagai lembaga intermediasi belum banyak menyalurkan pembiayaan PLS, sehingga tidak berpengaruh signifikan terhadap NPFps. Selain itu ditunjukkan adanya kelebihan likuiditas bank (Gambar 6). Islam dan Nishiyama (2016) menyatakan bahwa kelebihan likuiditas merupakan proxy masalah moral hazard antara manajemen bank dan deposan karena deposan tidak dapat memantau dan membuat manajemen terikat untuk pemanfaatan dana secara efektif. Dengan kata lain, deposan, sebagai pihak ketiga tidak dapat memantau biaya kelebihan likuiditas namun terkena dampak masalah moral hazard oleh bank atas pemanfaatan dana. Mengingat FDR sebagai kemampuan Jurnal Manajemen dan Organisasi (JMO),

Vol. 9 No. 3 Desember 2018, likuiditas bank, oleh karena itu, bank banyak meyalurkan pembiayaan jual beli atau dikenal murabahah yang memiliki kepastian return. Sedangkan Pertumbuhan Resrukturisasi Pembiayaan profit sharing juga tidak signifikan berpengaruh terhadap NPFps hal ini dapat dikarenakan 
perubahan NPFps setelah adanya restrukturisasi baru akan terlihat pada periode satu sampai tiga bulan setelah restrukturisasi, mengingat salah satu bentuk restrukturisasai ialah adanya penjadwalan ulang pembayaran kewajiban. Namun hal ini tidak dapat ditunjukkan dalam penelitian ini dikarenakan tidak tersedianya lag of time pada NPFps.

\section{KESIMPULAN}

Berdasarkan analisis model regresi data panel, dari keempat variabel pengukuran indikasi masalah keagenan disimpulkan bahwa Fungsi Agensi dan Investment Appeal berpengaruh negatif dan signifikan terhadap NPFps, sementara dua variabel lainnya yakni FDRps dan Pertumbuhan Restrukturisasi Pembiayaan bagi hasil, tidak berpengaruh signifikan terhada p NPFps. Dalam hal penyaluran pembiayaan, bank menerima risiko pembiayaan bermasalah oleh debitur baik secara langsung ataupun tidak langsung. Adanya masalah keagenan yakni moral hazard langsung oleh bank sebagai agen dimana fungsi agensi sebagai kemampuan bank dalam hal sumber dana, memberikan peluang atas ketidaksesuaian penggunaan sumber dana profit sharing pada penyaluran pembiayaan non profit sharing-murabahah. Juga dapat ditunjukkan bahwa bank risk averse terhadap pembiayaan PLS dilihat dari rendahnya pemanfaatan dana pihak ketiga yang disalurkan pada pembiayaan PLS. Selain itu, adanya peluang excessive risk taking dalam memperoleh return untuk deposan dan tingginya pemanfaatan return pembiayaan non-PLS atas pengembalian deposan profit sharing. Hal ini menjadi bukti bank memilih pembiayaan murabahah untuk mengantisipasi risiko likuiditas atas fungsi agensi dan pengembalian kepada deposan (Investment Appeal).

Pada laporan keuangan triwulan Bank Umum Syariah yang digunakan tidak menampilkan besaran alokasi masing-masing pembiayaan mudharabah dan musyarakah dan untuk sumber dana penyaluran pembiayaan bagi hasil yang dianalisis bukan merupakan dana investasi profit sharing yang mana deposan bisa kehilangan sebagian atau seluruh dananya seandainya bank merugi, melainkan dana pihak ketiga profit sharing atau disebut dana syirkah temporer, dimana dana tersebut selain dikelola untuk menghasilkan pendapatan dan bank bertanggung atas pengembalian dana tersebut. Hal ini menjadi perhatian bagi peneliti selanjutnya apakah sumber dana menjadi salah satu pengaruh penyaluran pembiayaan Bank Umum Syariah karena risk averse oleh bank terjadi karena keterbatasan jenis sumber dana tersebut. Terkait pengukuran masalah keagenan dimana hal ini merupakan perilaku prinsipal dan agen, diperlukan data primer terhadap prinsipal dan agen guna keakuratan pengukuran masalah keagenan.

\section{DAFTAR PUSTAKA}

Abdel, K. R., \& Archer, S. (2006). On capital structure, risk sharing and capital adequacy in Islamic Banks. International Journal of Theoretical and Applied Finance, 9, 269-280.

Aggarwal, R. K., \& Yousef T. (2000). Islamic Bank and Investment financing. Journal of Money, Credit and Banking, 32(1), 93-120.

Ardiansyah, M. (2014). Bayang-Bayang Teori Keagenan pada Produk Pembiayaan Perbankan Syariah. Jurnal Wacana Hukum Islam dan Kemanusiaan, 14(2), 151-269.

Astrini, K. S., Suwendra, I. W., \& Suwarna, I. K. (2014). Pengaruh CAR, LDR, dan bank size terhadap NPL pada lembaga perbankan yang terdaftar di Bursa Efek Indonesia. e-Journal Bisma Universitas Pendidikan Ganesha Jurusan Manajemen. 2(1).

Bank Indonesia. Statistik Perbankan Syariah 2014-2016. [diunduh 2017 April 25].

Bank Indonesia. Kodifikasi Peraturan Bank Indonesia: Penilaian Tingkat Kesehatan Bank. [diunduh 2017 Agustus 2].

Dar, H. A., \& Presley, J. R. (2011). Lack of Profit Loss Sharing in Islamic Banking: Management and Control Imbalances. International Journal of Islamic Financial Services, 2(2), 1-18.

Eisenhardt, K. M. (1984). Agency Theory: An Assessment and Review. The Academy of Management Review, 14(1), 57-74.

El-Tiby, A.M. (2011). Islamic Banking: How to Manage Risk and Improve Profitability. New Jersey: John Wiley \& Sons. 
Farag, H. (2016). Corporrate governance in Islamic financial institutions: what have we learnt? in Mallin C. A. (Ed) Handbook on Corporate Governance in Financial Institutions. Cheltenham: Edward Elgar.

Farag, H., Mallin, C., \& Ow-Yong, K. (2017). Corporate Governance in Islamic Banks: New Insight for Dual Board Structure and Agency Relationships. Journal of International Financial Markets, Institutions \& Money. doi: http://dx.doi.org/10.1016/j.intfin.2017.08.002.

Hamza, H. (2015). Does Investment Deposit Return in Islamic Banks Reflect PLS Principle?. Borsa Istanbul Review, 16(1), 32-42.

Harahap, R. M. (2016). Risiko Moral Hazard pada Perbankan Syariah di Indonesia. Al-Maslahah Jurnal Ilmu Syariah, 12(1), 1-20.

Hassan, M. K., \& Lewis, M. K. (2007). Handbook of Islamic Banking. Cheltenham: Edward Elgar.

Ibrahim, T., \& Ragimun. (2010). Moral Hazard Dan Pencegahannya Pada Industri Perbankan di Indonesia [internet]. [diunduh 2017 Agustus 25]. Tersedia pada: https://www.kemenkeu.go.id/sites/default/files/Moral\%20Hazard\%20Dan\%20Pencegaha nnya\%20Pada\%20Industri\%20\%20Perbankan\%20Di\%20Indonesia.pdf.

Idroes, F. N. (2011). Manajemen Risiko Perbankan. Jakarta: Raja Grafindo Persada.

Islam, M.S., \& Nishiyama, S. (2016). The Determinants of Non-performing Loans: Dynamic Panel Evidence from South Asian Countries. DSSR Discussion Papers, 64, 1-34.

Ismal, R. (2008). An Efficient Portfolio Frontier of The Islamic Financing Instruments. Proceeding book of an International Seminar and Symposium on Implementation of Islamic Economics to Positive Economics in The World. Surabaya: Universitas Airlangga.

Jensen, M. C., \& Meckling, W. H. (1976). Theory of the Firm: Managerial Behavior, Agency Costs and Ownership Structure. Journal of Financial Economics. 3, 305-360.

Kurniawati, R. (2008). Masalah Keagenan (Masalah keagenan) dalam Kontrak Mudaharabah di Bank Syariah. Jakarta, Indonesia: Universitas Indonesia.

Kurniawati, R. (2016). Bounded Rational dan Adverse Selection dalam Pembiayaan Bank Syariah: Kajian terhadap Masalah Keagenan dalam Penyaluran Pembiayaan Syariah. Bogor, Indonesia: Institut Pertanian Bogor.

Louati, S., Abida, I. G., Boujelbene, Y. (2015). Capital adequacy implications on Islamic and non-Islamic bank's behavior: Does market power matter?. Borsa Istanbul Review, 15(3), 192-204.

Manzilati, A. (2011). Kesepakatan Kelembagaan Kontrak Mudharabah dalam Kerangka Teori Keagenan. Jurnal Keuangan dan Perbankan. 15(2):281-293.

Iqbal, M., Ali, S. S., \& Muljawan, D. (2007). Advance in Islamic Economics and Finance. Proceedings of $6^{\text {th }}$ International Conference on Islamic Economics and Finance. Jeddah: Islamic Development Bank; Islamic Research and Training Institute.

Prasetyo, P. A., \& Burhan, M. U. (2013). Identifikasi Faktor Yang Mempengaruhi Rendahnya Pembiayaan Bagi Hasil Perbankan Syariah (Studi Kasus PT. BRI Syariah Kantor Cabang Malang). Jurnal Ilmiah Mahasiswa FEB Universitas Brawijaya. 1(2).

Rivai, V., \& Arifin, A. (2010). Islamic Banking: Sebuah Teori, Konsep, dan Aplikasi. Jakarta (ID): Bumi Aksara.

Sadr, K., \& Iqbal, Z. (2002). Choice Between Debt And Equity Contracts and Asymmetrical Information Information: Some Empirical Evidence. In: Iqbal M, Lleyllyn DT (edts.). Islamic Banking and Finance: New Perspective on Profit-Sharing and Risk. Cheltenham (UK): Edward Elgar. 139-154.

Siringoringo, R. (2012). Karakteristik dan Fungsi Intermediasi Perbankan Indonesia. Buletin Ekonomi Moneter, 15(1), 61-83.

Jurnal Manajemen dan Organisas (JMO),

Vol. 9 No. 3 , Desember 2018,
OJK. (2016). Statistik Perbankan Syariah. Jakarta: OJK

Usanti, T. P. (2006). Restrukturisasi Pembiayaan sebagai Salah Satu Upaya Penanganan Pembiayaan Bermasalah. Persfektif, 11(3), 258-281. 
Wiliasih, R. (2005). Profit Sharing dan Moral Hazard dalan Penyaluran Dana Pihak Ketiga Bank Umum Syariah di Indonesia. Depok, Indonesia: Universitas Indonesia.

Yahya, M., \& Agunggunanto, E. Y. (2011). Teori Bagi Hasil (profit and loss sharing) dan Perbankan Syariah dalam Ekonomi Syariah. Jurnal Dinamika ekonomi Pembangunan, $1(1), 65-73$. 